Women on the Verge 
Asia-Pacific:

\section{Culture, Politics, and Society}

Editors: Rey Chow, H. D. Harootunian,

and Masao Miyoshi 


\title{
Women on the Verge
}

Japanese Women, Western Dreams

\author{
KAREN KELSKY
}

Duke University Press $\cong$ Durham and London 2001 
(C) 200I Duke University Press All rights reserved

Printed in the United States of America on acid-free paper $\infty$ Typeset in Scala by Keystone Typesetting, Inc.

Library of Congress Cataloging-in-Publication Data appear on the last printed page of this book. 
For Taro, Miyako, and Seiji 
